SPATIAL LOCK-IN:

Do Falling House Prices Constrain Residential Mobility?

\author{
SEWIN CHAN \\ Department of Economics \\ Rutgers University \\ February 1998
}




\section{SPATIAL LOCK-IN: Do Falling House Prices Constrain Residential MobiLity?}

Falling house prices have caused numerous home owners to suffer capital losses. Those with little home equity may be prevented from moving because proceeds from the sale of their house are insufficient to repay their mortgage and provide a new down payment. A data set of mortgages is used to examine the magnitude of these constraints. Estimates show that average mobility would have been $24 \%$ higher after four years, had real house prices increased at 1980 s rates, and $10 \%$ higher if house values had merely kept up with inflation. Among those with high initial loan-to-values, the differences are even greater.

JEL Codes: R23, R21 


\section{INTRODUCTION}

The last recession brought with it a sharp fall in house prices in many parts of the United States, and home owners were taken by surprise as they saw the primary component of their wealth diminish and their hopes to move thwarted. As widely reported by the media, owners who suffered severe house price declines often had mortgage balances that were higher than the value of their house ${ }^{1}$. Once a household has a mortgage balance greater than approximately 90 percent of their total assets (predominantly the house value), it becomes spatially locked. The household is not able to repay the mortgage and make a down payment on a new home since banks generally do not issue mortgages with loan-to-value ratios greater than 95 percent, and the transactions costs associated with selling and buying a new home typically exceed 5 percent of the house value ${ }^{2}$.

This paper uses a set of mortgages to examine the degree to which these capital losses constrain home owners from moving. According to the estimates, the number of households that moved would have been 24 percent higher after 4 years, had real house prices increased at their 1980s rates, and 10 percent higher if house values had just kept up with the rate of inflation.

\footnotetext{
${ }^{1}$ For example, The New York Times writes ....For many who bought starter houses in the middle 80s, the fall in prices has forced the postponement of purchase and relocation decisions that are essential to long-term family wellbeing. Unable to recover all their equity if they sell, these families are unable to buy and “move up”... (19 September 1993).

${ }^{2}$ According to DiPasquale and Wheaton (1996), realtor fees for selling the current home range from 3 to 6 percent of the sale price, and closing costs on a new home, 1 to 3 percent of the purchase price. In addition, bridge financing, which allows the buyer to purchase the new home while the old one is being sold, costs almost 1 percent of the house value for every month of dual ownership.
} 
Among home owners with high initial loan-to-value ratios, these increases are even higher, at 32 and 15 percent respectively.

Since over two thirds of households are home owners, the majority financing with a mortgage ${ }^{3}$, the mobility constraints can have significantly damaging economic effects. Studies have shown that mobility plays a predominant role in macroeconomic adjustment; for example, Blanchard and Katz (1992) demonstrate that the principal regional adjustment mechanism in the U.S. is labor mobility rather than job creation or job migration. When regional imbalance exists, workers move to jobs rather than vice versa ${ }^{4}$. Therefore, the housing market could be hindering the spatial allocation of labor as households are locked out of alternative markets with better income prospects 5 .

The situation is exacerbated by the fact that negative employment shocks are correlated with nominal house price changes ${ }^{6}$. In a local market, the demand for housing depends on the level of amenities and the income of the residents, while the supply of housing is inelastic in the short-run. A decline in local wages shifts the demand for housing inwards which leads to a

\footnotetext{
${ }^{3}$ According to the 1990 U.S. Census, 69 percent of households are home owners and 67 percent of home owners have an outstanding mortgage. Among home owners who moved into their homes within the previous five years, 84 percent have a mortgage.

${ }^{4}$ See similar findings by DaVanzo (1978), Topel (1986), Barro and Sala-i-Martin (1991), Bartik (1991) and Borjas, Bronars and Trejo (1992).

${ }^{5}$ The constraints to mobility discussed here are somewhat different in nature from those of job-lock due to employer provided health care benefits (see Madrian (1994)) or defined benefit pension plans. In this paper, spatial lock-in refers only to residential mobility; the worker is constrained in choice of dwelling but may be free to switch jobs without penalty. However, as far as spatial adjustment of the labor market is concerned, the two mechanisms have essentially the same effects: workers are discouraged from looking for jobs in other regions because moving away from their present residence would involve significant losses.

${ }^{6}$ See Bartik (1991), Blanchard and Katz (1992) and Caplin et al. (1997) for empirical estimates.
} 
decline in house values. Thus, a great degree of risk is introduced into the home owner's portfolio as there is a positive covariance between its two most important assets: human capital and housing capital. Eventually, out-migration of workers should mitigate the decline in wages; but in the short run, lock-in occurs precisely when households would most want to move.

The primary reason for these lock-in constraints is the dominance of housing in the household's asset portfolio: owner-occupied housing represents almost one third of total household net worth and the median household has close to 100 percent of non-pension assets in residential housing ${ }^{7}$. If households did not have such a huge proportion of their portfolio tied to their homes, then a real estate downturn would be less likely to lead to spatial lock-in because the household would have other assets to cover the losses. However, housing is as much an item in the consumption bundle as it is an investment vehicle, and allocating fewer assets to housing would imply reduced housing consumption, which households are evidently unwilling to accept given their revealed preference. Brueckner (1995) demonstrates clearly how optimal housing consumption decisions can lead to tremendous distortions in the efficient asset portfolio frontier.

Nevertheless, until the collapse in prices, over-investing in housing (in an efficient portfolio sense) was not much of a concern since housing was viewed as a good investment with high capital gains potential. Together with the indivisibility of the ownership decision and the tax advantages of owning, households did not fare badly in concentrating most of their assets into home ownership. However, the years of house prices always outstripping inflation appear to be over. In addition, lock-in effects may be more severe than suggested by aggregate house price declines since owners are also subject to idiosyncratic risk. The results of Case and Shiller 
(1989) and Goetzmann and Ibbotson (1990) suggest that individual home owner risk is approximately three or four times that of the market risk.

This paper illustrates the severity of spatial lock-in constraints and the pressing need for innovations in housing finance to separate the consumption aspect of housing from investment. The remainder of this paper is organized as follows. Section II reviews related literature and describes the various options available to spatially locked households who want to move. The data to be used in the analysis are presented in section III, the econometric strategy in section IV, and the results of the empirical analysis in section V. Conclusions are given in section VI.

\footnotetext{
${ }^{7}$ Federal Reserve Board, Balance Sheets of the U.S. Economy and the 1990 Consumer Expenditure Survey (average includes non-home owners).
} 


\section{SPATially Locked HouseholdS}

For spatially locked home owners, the fall in house prices was largely unanticipated. The survey by Case and Shiller (1988) shows that households appear to be backward looking in their house price forecasts and that home owners in areas that had experienced price gains in the late 1980s thought that prices would continue to rise even though the trend had already flattened or even declined. Once prices begin to fall, some households will become spatially locked; not only are they unable to finance a down payment on a new home from the sale proceeds of their current home, they will also need additional funds to repay the existing mortgage ${ }^{8}$.

In order to qualify for a mortgage on another home, a borrower will typically have to make a down payment of at least five to ten percent, and any borrower with less than twenty percent down payment has to pay for additional private mortgage insurance which essentially raises the interest rate for as long as the loan is above 80 percent loan-to-value. In addition to this pure down payment constraint, borrowers also face an income constraint in loan qualification. As a rule of thumb, mortgage banks will not lend more than three times a borrower's income, so if the household has also suffered an income shock, an even higher down payment would be needed to bring the loan-to-income ratio down to the lender's maximum. Since households who do not move are not subject to the same requirements and are allowed to remain in a home with low or negative equity, mobility can be severely hindered by a fall in house prices.

\footnotetext{
${ }^{8}$ It is nominal house value declines that give rise to spatial lock-in since the mortgage is denominated in nominal dollars. If house values fell in real but not nominal terms, lock-in would not occur as the house would still be worth more than the balance on the mortgage.
} 


\section{Spatial Lock-in}

Stein (1995) has constructed a theoretical model that illustrates how the effects of down payment constraints on repeat buyers can reduce mobility. When prices fall, households who must rely on the sale of their current home for the down payment on a new home may be prevented from moving. Constrained households may "fish" for a buyer: list the house for sale at a price above market in the hope that a buyer will be found. Genesove and Mayer (1997) use a sample of condominiums listed for sale in Boston to test this hypothesis. Their results show that high loan-to-value (LTV) properties take much longer to sell, and that if a sale occurs, the transaction price is significantly higher than for properties with low LTVs.

There has been little direct empirical evidence on the extent of this lock-in effect at the household level, although several studies suggest that mortgage qualification requirements are likely to constrain household behavior. Engelhardt (1996) shows that households significantly increase consumption following the purchase of a new home, Linneman and Wachter (1989) find evidence that income and wealth constraints affect the home ownership decision and Zorn (1989) finds that almost two thirds of households are constrained into purchasing less owner-occupied housing than they would like. Caplin, Freeman and Tracy (1998) observe that many households living in areas that suffered house price declines do not refinance their fixed rate mortgages even though they have large financial incentives to do so, suggesting that home owners who want to move may similarly be constrained from doing so.

There are very few options available for a negative equity (or close to negative equity) household if they want to move. In most states, defaulting on a mortgage is not an option unless it is accompanied by a bankruptcy filing, since the mortgagee has the right to come after the borrower's other assets when the property's value is insufficient to cover the mortgage. Declaring bankruptcy is a very costly process, and the better the household's credit history, the 
more they have to lose. A bankruptcy filing will remain on a borrower's credit report for 7 years, severely affecting the costs of future borrowing.

Alternatively, the constrained household could rent out the negative equity house and either buy a new house using any remaining assets or move into rental property; but this decision is fraught with complications. First, the costs of renting out the existing property as an absentee landlord are substantial. Finding a suitable tenant involves search costs, and rental income after taxes may not be sufficient to cover mortgage payments and other expenses especially since falling house prices are correlated with falling rents. A management agent may be needed and maintenance costs will be higher than under owner-occupation as the tenant does not have an incentive to keep the property in good condition ${ }^{9}$. It can also be extremely difficult to evict a tenant in some areas, even if rent payments are delinquent. Second, if the household does decide to rent out the existing property and buy a new home, it would have to find sufficient additional assets to cover a new down payment and it would have to take on yet more real estate debt. Third, if the household decides to rent a new home, they may not be able to find a desirable rental unit in a desirable location: rental properties are often different in both physical and neighborhood attributes from owner-occupied ones and there are many types of owner-occupied houses that have no rental substitute.

Thus, a spatially locked household is not left with many options except to remain in the negative equity home, with the hope that prices eventually appreciate. We now turn to the data used to examine empirically the extent of this spatial lock-in.

\footnotetext{
${ }^{9}$ Management agents in the New York metropolitan area typically take 20 percent of the rent plus any additional maintenance costs. Owners are told to expect at least a one month vacancy rate each year.
} 


\section{The Data}

\section{A. The Chemical Bank Mortgage Sample}

The data are a sample of residential single-family 30 -year mortgages originated in New York, New Jersey and Connecticut between November 1989 and January 1994 by Chemical Bank, one of the largest commercial banks in this region. The sample is representative of borrowers that meet the underwriting standards of Fannie Mae (the Federal National Mortgage Association): they have no bankruptcies, no serious delinquencies in the past two years, few new credit inquiries in the past year, and are current on all accounts ${ }^{10}$. These types of borrowers account for 90 percent of the total market ${ }^{11}$. They are less likely to be constrained than those with poor credit, and so there will be a bias against finding evidence of spatial lock-in.

The data contain all the information found on a mortgage application form after verification by underwriters. Both refinances and purchases of new homes are represented. Loan performance is tracked by recording all payments, prepayments, defaults and delinquencies. Prepayments can arise due to refinancing of the mortgage or sale of the property; the data do not

\footnotetext{
${ }^{10}$ The Fannie Mae underwriting standards have become the mortgage industry norm for "good" credit mortgages, also known as "A paper". The "bad" credit market, also known as "B,C paper" or "hard money lending" charges much higher interest rates and up front mortgage points. Roughly speaking, depository institutions (commercial banks and thrifts) originate good credit loans, and non-depository institutions (specialist mortgage bankers and mortgage brokers) originate both types of loans. In either case, mortgages are typically sold to secondary market conduits; originators are merely acting as middle-people in a long transaction between the borrower and the ultimate investor. It is likely that depository institutions specialize in good credit loans since they have to maintain an image and reputation for stability on the deposit side, even though bad credit loans maybe a profitable business and a wholly diversifiable risk.

${ }^{11} 90$ percent of the total securitized conventional (i.e., non-government) mortgage market, by dollar value. Source: Moody's Investor Service.
} 
allow differentiation between the two. This poses a problem for using mortgage duration as a proxy for housing duration, especially when interest rates are falling, as they do towards the end of the sample period. There are likely to be an unacceptable number of type II errors: households that are classed as moving but have merely refinanced their mortgage. For this reason, fixed rate mortgages (FRMs) are removed from the sample ${ }^{12}$. Among the remaining adjustable rate mortgages (ARMs) there is very little refinancing since the mortgage contract includes an option to convert to a fixed rate loan at the market rate (a relatively small conversion fee is charged compared with the substantial cost of refinancing the mortgage). From a subsample of 140 terminated ARMs from New York City that were matched with records of deeds and uniform commercial codes (title to co-op apartments) filed at the New York City Department of Finance, there were only 3 in which ownership of the property did not change ${ }^{13}$. Thus, we can conclude that for ARMs, mortgage duration is a good proxy for housing duration with respect to these type II errors.

Unfortunately, there is no easy way of checking the extent of type I errors in the sample: households who move without terminating the mortgage. Insofar as these households are likely to be renting out their house to others while living elsewhere, an extremely small 3 percent of households in the 1990 Consumer Expenditure Survey report any sort of rental income, and these

\footnotetext{
12 The adjustable rate sample will also be representative of the fixed rate sample if both types of borrowers react to house prices in a similar fashion proportionately. ARMs tend to be chosen by the more mobile, as shown in ARMFRM choice models (see Brueckner and Follain (1988)), so if FRM households are little inclined to move, the level of mobility will tend to be overestimated by focusing on ARM households. However, here we are investigating changes in the mobility rate due to falling house prices, and are only interested in households who want to move. Since there is little reason to believe that among households who want to move, lock-in will affect FRM and ARM households any differently, the findings can be taken to be representative of both types of borrowers.

${ }^{13}$ This search was conducted using a database of public records owned by Public Data Corporation.
} 
will include owners of vacation homes, landlords of multi-family residences and others who bought properties purely for investment purposes.

The resulting sample consists of 5,778 observations, with 5,094 non-movers and 684 movers as of January 1994, the last date that behavior is observed. Approximately 2 percent of the loans defaulted and these are treated as censored observations; excluding them from the sample or including them as movers gives similar results. Table 1 shows summary statistics measured at the time of mortgage origination, based on move status at the end of the sample period. On average, movers have higher appraised property values, lower loan-to-value ratios (LTVs) as well as higher assets and incomes. Their demographic composition is also different: they are more likely to be married and have children, and less likely to be a female headed household ${ }^{14}$ or prior owners. Movers are less likely to have paid mortgage points, consistent with there being little incentive to pay points up front in exchange for a lower interest rate if the mortgage is not going to be held very long ${ }^{15}$.

Figure 1 shows the distribution of loans by initial loan-to-value. The large number of loans at 80 percent is explained by the fact that private mortgage insurance (PMI) has to be paid at initial LTVs of greater than 80 percent. The PMI is charged as a percentage of the entire loan balance, not just the marginal amount above 80 percent LTV, and so those who would have otherwise chosen an LTV slightly above 80 percent have a strong financial incentive to accumulate a larger down payment in order to reduce the ratio to 80 percent. Only those without

\footnotetext{
${ }^{14} \mathrm{~A}$ female headed household in this sample is one in which the sole borrower is female (whether she is single or not), or both the primary and secondary borrowers are female.

${ }^{15}$ Mortgage points are simply a percentage of the loan amount that can be paid upfront to the lender in exchange for a reduction in the interest rate.
} 


\section{Spatial Lock-in}

the necessary up-front cash will pay the PMI. Thus, there is an a priori reason to believe that those who have initial LTVs above 80 percent are more likely to be constrained than those at or below 80 percent.

Table 2 gives summary statistics by initial LTV status. Differences between high and low LTV households are evident: higher initial LTV properties have lower mobility rates, lower appraised values, the households have less income, fewer other assets and are generally younger with less prior ownership experience.

\section{B. House Price Performance and Contemporaneous LTV}

To assess with absolute precision the effects of property market declines on mobility, the market value of every home would have to be known in every period. Unfortunately and not unsurprisingly, such data is unavailable. As a proxy, we use county level weighted repeat sales house price indices constructed using the methodology of Case and Shiller $(1987)^{16}$. The average cumulative price decline, across all the counties, during the entire sample period (November 1989 to January 1994), was 6.7 percent, with quite a large standard deviation of 5.7.

A measure of contemporaneous LTV is constructed based on the outstanding loan balance in each month, and the appropriate house price index. The average cumulative increase in contemporaneous LTV after 3 years was 4.2 percentage points among households who remained non-movers, and 2.2 percentage points among households that moved within the

\footnotetext{
${ }^{16}$ County level indices for New York, New Jersey and Connecticut were obtained from Case Shiller Weiss, Inc.. These included most counties represented in the Chemical Bank sample. The exceptions were Manhattan and Queens, for which we used a similarly constructed index for the New York City PMSA, compiled by Freddie Mac.
} 
sample time frame. Thus there is already some evidence of lock-in among those that have experienced falling house values.

Table 3 shows a comparison of counties that were above and below the median in cumulative house prices changes over the sample period, using information from the 1990 U.S. Census. The self-reported house values, household income and demographic characteristics of home owners with mortgages are not substantially different between the two groups. Thus, there does not appear to an obvious pattern of sorting by households into counties that experience falling house prices and those that do not. 


\section{ECONOMETRIC STRATEgY}

The goal is to derive unbiased estimates of spatial lock-in by examining the behavior of households living in areas with different house price dynamics. We begin by estimating a proportional hazard housing spell duration model:

$$
\mathrm{h}_{\mathrm{i}}\left(\mathrm{t}, \alpha, \beta, \gamma, \mathrm{Z}_{\mathrm{it}}\right)=\exp \left[\mathrm{g}(\mathrm{t}, \alpha)+\gamma_{0}+\gamma_{1} \mathrm{LTV}_{\mathrm{it}-1}+\gamma_{2} \mathrm{HP}_{\mathrm{it}-1}+\gamma_{3} \mathrm{LTV}_{\mathrm{i} 0}+\beta^{\prime} \mathrm{X}_{\mathrm{i}}+\mathrm{u}_{\mathrm{i}}\right]
$$

where $\mathrm{i}$ refers to each household, the hazard rate $\mathrm{h}($.$) is the probability of moving after \mathrm{t}$ periods conditional on not having moved before t periods, $\alpha, \beta$ and the $\gamma$ 's are the parameters to be estimated, $Z_{i t}$ is the vector of explanatory variables, $\exp [\mathrm{g}()$.$] is the baseline hazard, and \mathrm{u}$ is the error term.

The explanatory variables include the lagged contemporaneous LTV $\left(\mathrm{LTV}_{\mathrm{it}-1}\right)$ which captures the potential for spatial lock-in. A household with a contemporaneous LTV of over approximately 95 percent will be unable to repay their mortgage from the sale proceeds of the house ( 5 percent transactions costs included), and a household with an $\mathrm{LTV}_{\mathrm{it}-1}$ of over 90 percent will be unable to repay their mortgage and make a minimal down payment on a new home. The coefficient $\gamma_{1}$ can be used to test the lock-in hypothesis, i.e., $H_{0}: \gamma_{1}=0, H_{1}: \gamma_{1}<0$. A one month lag $(\mathrm{t}-1)$ is used for all time-varying contemporaneous variables since it would take at least this long for home owners to implement a decision to move; a two period lag is also tested.

$\mathrm{HP}_{\mathrm{it}-1}$ is the cumulative growth in the county's house prices from the time the mortgage is originated to the previous period. Even in the presence of the contemporaneous LTV, the cumulative effect of house prices $\mathrm{HP}_{\mathrm{it}-1}$ may still be significant if there are unconstrained households who are unwilling to realize a capital loss. Kahneman, Knetsch and Thaler (1990) provide experimental evidence on this loss aversion phenomenon, and discuss how individuals 
tend to be reluctant to sell at a loss because of a perceived entitlement to a former price, leading to seemingly irrational behavior.

$\mathrm{LTV}_{\mathrm{i} 0}$ is a high initial LTV indicator (equal to one if intial LTV is strictly greater than 80 percent) that captures any unobservable characteristics that may determine mobility behavior and are correlated with initial LTV. As discussed above (in section III A), there is reason to believe that those who have initial LTVs above 80 percent are more likely to be constrained than those at or below 80 percent.

$\mathrm{X}_{\mathrm{i}}$ is a vector of covariates that may explain other systematic differences in mobility behavior, such as age, children and prior home ownership. Mortgage points are included as they have been shown to be an indicator of ex ante mobility expectations in non-falling interest rate environments ${ }^{17}$. Banks typically allow borrowers to reduce the interest rate on a mortgage by paying a percentage of the loan amount up front. The value of the rate discount clearly depends on how long the mortgage is held and therefore, the points decision can be used as a revealed preference sorting device to determine whether households have a high ex ante probability of moving soon. Ex post, any points paid are a sunk cost, so the mortgage points indicator of expected mobility can be interpreted as another household characteristic included in the $\mathrm{X}_{\mathrm{i}}$ vector that denotes an otherwise unobservable propensity to move.

We also include variables that relate to the propensity of moving even if negative equity is encountered, such as income, and the presence of other assets. Ideally, we would like a measure of contemporaneous "extended LTV" where

\footnotetext{
${ }^{17}$ See Chan (1996) and Brueckner (1994) for detailed explanations. This interest rate-mortgage point trade-off and its relation to expected holding length is documented in both trade and consumer publications.
} 


$$
\text { extended LTV }=\frac{\text { loan balance }- \text { other assets }}{\text { house value }}
$$

Thus, the variable of interest is other assets as a proportion of the house value and we would expect a positive coefficient in our estimations. Unfortunately, a contemporaneous measure of other assets is not at hand; we can only proxy with the level of assets reported to and verified by underwriters at the time the mortgage is booked. Errors arise since households have little incentive to report more assets than is sufficient to comfortably qualify them for the mortgage, and in any case, their asset positions may have changed over time. Similarly, errors arise from using initial reported income as a proxy for contemporaneous income.

Mortgage interest rates were historically low and falling during some of the sample period and may have given an added incentive for households to move since they could take out a new mortgage at a low rate. Thus, we include the contemporaneous market interest rate for fixed rate mortgages into the estimation.

A version of the proportional hazard model that incorporates splines to fit the baseline hazard is used to estimate equation $[1]^{18}$. The baseline $\exp [\mathrm{g}()$.$] is flexibly modeled as \mathrm{J}$ sequential polynomials in time, with smooth transitions between each polynomial:

$$
g(t, \alpha)=\sum_{j=1}^{J} \omega_{j}(t)\left[\alpha_{0 j}+\alpha_{1 j} t\right]
$$

The parameters $\alpha$ determine the shape of each component and the weights $\omega$ determine the amount of smoothness between the components. The weights are chosen to smooth the transition between any two components so that the hazard is a weighted average of the two. The smoothing factors used are: 


$$
\omega_{\mathrm{j}}(\mathrm{t})=\Phi_{\mathrm{j}}\left(\frac{\mu_{\mathrm{j}}-\mathrm{t}}{\sigma_{\mathrm{j}}}\right)-\Phi_{\mathrm{j}}\left(\frac{\mu_{\mathrm{j}+1}-\mathrm{t}}{\sigma_{\mathrm{j}+1}}\right)
$$

where $\Phi$ denotes the cumulative standard normal distribution function. The means $\mu$ locate the transitions while the standard deviations $\sigma$ determine the amount of smoothness in the transitions.

${ }^{18}$ This method has been used by Hoynes (1996), among others. 


\section{EMPirical RESUlts}

Table 4 presents the hazard estimates. A positive coefficient implies that the hazard of moving is higher as the covariate rises. Column 1 presents the baseline hazard. Only two polynomials were required to estimate the baseline:

$$
g(t, \alpha)=\omega_{1}(t)\left(\alpha_{00}+\alpha_{01} t\right)+\omega_{2}(t)\left(\alpha_{10}+\alpha_{11} t\right)
$$

where

$$
\omega_{1}(\mathrm{t})=1-\Phi\left(\frac{\mathrm{t}-\mu}{\sigma}\right) \quad \omega_{2}(\mathrm{t})=\Phi\left(\frac{\mathrm{t}-\mu}{\sigma}\right)
$$

and the best fit was found to be $\mu=28$ months and $\sigma=3$. The baseline is graphed along with the empirical hazard in Figure $2^{19}$.

Column 2 of table 4 presents the baseline hazard together with the contemporaneous LTV, the cumulative growth in house prices lagged one period, and the high initial loan-to-value dummy variable. The coefficient of interest, $\gamma_{1}$, is negative and significant at one percent, confirming the lock-in hypothesis. The cumulative effect of house prices is not significantly different from zero, which is somewhat surprising given (in the author's opinion) our predispostion to loss aversion. Perhaps households are moving to another area with similarly low house values, in which case there is no "loss" from having moved. The high initial LTV dummy which captures any systematic differences between households who were and were not able to obtain the more favorable 80 percent (or less) LTV mortgage has a coefficient that is

\footnotetext{
${ }^{19}$ Estimation following the traditional Cox regression for parameterizating the baseline hazard yielded a poorer fit for the baseline, but similar qualitative results for the explanatory variables.
} 
insignificant and has the wrong $\operatorname{sign}^{20}$. Thus we can conclude that lock-in derives solely from contemporaneous LTV; there are no additional effects through house prices or initial LTV.

Using a dummy variable for almost-negative-equity (equal to one if greater than 95 percent LTV and zero otherwise) or a variable equal to LTV if greater than 95 percent and zero otherwise is perhaps an even more precise measure of lock-in since the mortgage market enforces this discontinuity. Below approximately 95 percent LTV, a household can sell the house and repay the mortgage plus other transactions costs (although in the absence of other assets, the household could not afford a down payment to purchase a new house - they would have to rent); above 95 percent, moving becomes increasingly hard as the household needs other assets to cover the capital loss and any down payment on a new house. Not surprisingly, both variables gave highly significant results for any LTV threshold between 90 and 100 percent, however the value of the likelihood function was not as high as for the continuous measure. This is perhaps due to the imprecision of the contemporaneous LTV - the house price index is a market index that does not include any idiosyncrasies that may be present for each household.

In column 3, we try to take into account that a household with sufficient other assets will be able to overcome any negative equity effects and be able to move. We see that the coefficient on this variable is positive but insignificant. Although this is likely due to the crudeness of the proxy, it is also possibly attributable to the rigidity of mental accounts, of the sort described by Shefrin and Thaler (1988). Under this premise, funds are not fungible between different mental accounts and individuals will not use other assets to cover their housing market losses.

\footnotetext{
${ }^{20}$ Entering $\mathrm{LTV}_{0}$ as a continuous variable, or as a variable that is equal to $\mathrm{LTV}_{0}$ only when $\mathrm{LTV}_{0}$ is greater than 80 percent, does not change this result.
} 
In column 4 , other explanatory variables are added. Being married significantly increases the likelihood of moving, and the effect of having children is also positive, though insignificant. Female heads of household have significantly reduced mobility. Being younger than 40 significantly increases mobility, consistent with life-cycle predictions. Being older than 55 also increases mobility, but this coefficient is insignificant. More educated heads of household have significantly higher mobility rates while prior ownership is positive but insignificant. Higher income households are significantly more mobile, perhaps reflecting the fact that they are more able to overcome any negative equity constraints.

The mortgage points variable is equal to one if the household paid mortgage points and the loan was booked before the period of falling interest rates starting in 1992, and zero otherwise. As expected, the coefficient is negative and significant: if a household paid points to reduce the interest rate, they are less likely to move. The contemporaneous mortgage rate (the Freddie Mac rate for fixed rate mortgages lagged one period) is significant and negative, reflecting a greater incentive to move when the cost of new mortgages is lower.

Our variable of interest, $\gamma_{1}$, remains negative and significant at one percent. The size of the coefficient on contemporaneous LTV in column 4 implies that an increase in contemporaneous LTV from 90 to 100 percent will lead to a 15 percent decrease in the mobility hazard. A lag of two months on the contemporaneous variables, or no lag at all, did not yield noticeably different results.

Figure 3 shows the result of a simulation that takes the households in the sample, changes the monthly real house price growth to the average prevailing during the previous period of rising house prices, 1982-89, when house prices were rising at an average real rate of 4 percent per 
annum $^{21}$. These simulated hazard rates are contrasted with those estimated using the actual house price movements. The graphs show the difference in cumulative unconditional moving probabilities generated by the hypothetical and actual house price movements. After 4 years, the average mobility rate among the entire sample would have been 24 percent higher had house prices moved according to the 1980s rates. Among the subset of households with initial LTVs greater than 80 percent, the increase would have been 32 percent.

Figure 4 shows the result of a similar simulation, this time keeping house prices at a very modest real growth rate of zero. After 4 years, the increase for all households is 10 percent, and among households with initial LTVs greater than 80 percent, the increase would have been 15 percent.

\footnotetext{
${ }^{21}$ Average national house price growth is calculated from the Freddie Mac Weighted Repeat Sales Index, and deflation is based on the US city average consumer price index for all items, from the Bureau of Labor Statistics.
} 


\section{CONCLUSIONS}

The empirical findings provide clear evidence that there are severe constraints to mobility as a result of housing market shocks. The average mobility rate would be 24 percent higher after 4 years if house values followed the path of the previous seven years, and 10 percent higher if house values had merely kept up with the rate of inflation. Households with high loan-to-value ratios are particularly constrained.

An explicit welfare loss calculation is beyond the scope of this paper, but possible consequences can be noted. The loss of labor mobility will have damaging impacts for the smooth functioning of the economy as people move in response to labor market incentives and mobility arbitrages wage and unemployment differentials across regions. There will also be a welfare loss from misallocating housing and local public goods.

The constraints stem from the massive concentration of housing in the household's asset portfolio that is a consequence of housing being both a consumption good and an investment vehicle. For those who are already spatially locked, the options are few except to wait for future appreciation. However, in the longer run, there are possibilities for the design of new contracts that mitigate these mobility constraints by introducing some form of risk sharing. Caplin et al. (1997) propose a system of housing partnerships whereby a household and financial institution take joint ownership of the property; upon sale, both partners receive pro rata shares of the proceeds. The major benefit of such a proposal is that it reduces the amount of debt that households require to enjoy the benefits of home ownership, and thus lowers the concentration of real estate in their portfolios. Another approach that allows individuals to diversify their portfolios is the price index futures of Shiller and Weiss (1994) where the home owner takes out 
a futures contract on a house price index and would be compensated if the index fell below a predetermined minimum.

Given the importance of mobility to the macroeconomy and the welfare of consumers, there is an obvious need for more research in this area to write more efficient contracts, prevent spatial lock-in constraints and facilitate the operation of mobility. 


\section{REFERENCES}

Barro, Robert and Sala-i-Martin, Xavier, "Convergence across States and Regions," Brookings Papers on Economic Activity (1991), 107-82.

Bartik, Timothy J. Who Benefits from State and Local Economic Development Policies?

Kalamazoo, Michigan: W.E. Upjohn Institute for Employment Research, 1991.

Blanchard, Olivier and Katz, Lawrence, "Regional Evolutions," Brookings Papers on Economic Activity (1992), 1-62.

Borjas, George J.; Bronars, Stephen G. and Trejo, Stephen J, "Self-Selection and Internal Migration in the United States," Journal of Urban Economics 32 (Sept. 1992), 159-85.

Brueckner, Jan K. and Follain, James R., "The Rise and Fall of the ARM: An Econometric Analysis of Mortgage Choice," Review of Economics and Statistics 70 (Feb. 1988), 93102.

Brueckner, Jan K, “Borrower Mobility, Adverse Selection and Mortgage Points,” Journal of Financial Intermediation 3 (Sept. 1994), 416-441.

Brueckner, Jan K, "Consumption and Investment Motives and the Portfolio Choice of Home owners," University of Illinois, 1995.

Caplin, Andrew; Chan, Sewin; Freeman, Charles and Tracy, Joseph, Housing Partnerships: A New Approach to a Market at a Crossroads, Cambridge, MA: MIT Press, May 1997. Caplin, Andrew; Freeman, Charles and Tracy, Joseph, “Collateral Damage: How Refinancing Constraints Exacerbate Regional Recessions," Journal of Money Credit Banking, forthcoming 1998. 
Case, Karl E. and Shiller, Robert J, "Prices of single-family homes since 1970: New indexes for four cities," New England Economic Review (Sept./Oct. 1987), 45-56.

Case, Karl E. and Shiller, Robert J, "The Behavior of Home Buyers in Boom and Post-Boom Markets," New England Economic Review (Nov./Dec. 1988), 29-46.

Case, Karl E. and Shiller, Robert J, "The Efficiency of the Market for Single-Family Homes," American Economic Review 79 (Mar. 1989), 125-37.

Chan, Sewin, "Residential Mobility and Mortgages," Regional Science and Urban Economics 26, (June 1996), 287-311.

DaVanzo, Julie, "Does Unemployment Affect Migration? Evidence from Micro Data," Review of Economics and Statistics 6 (Nov. 1978), 504-14.

DiPasquale, Denise and Wheaton, William C, Urban Economics and Real Estate Markets, New Jersey: Prentice Hall, 1996.

Engelhardt, Gary V, "Consumption, Down Payments and Liquidity Constraints," Journal of Money, Credit and Banking 28 (May 1996), 255-71.

Genesove, David and Mayer, Christopher J, "Equity and Time to Sale in the Real Estate Market," American Economic Review 87 (June 1997), 255-69

Goetzmann, William N. and Ibbotson, Roger G, "The Performance of Real Estate as an Asset Class," Journal of Applied Corporate Finance 3 (1990), 65-76.

Hoynes, Hillary Williamson, "Welfare Transfers in Two Parent Families: Labor Supply and Welfare Participation Under AFDC-UP," Econometrica 64 (Mar 96), 295-332.

Kahneman, Daniel; Knetsch, Jack L. and Thaler, Richard H, “Experimental Tests of the Endowment Effect and the Coase Theorem," Journal of Political Economy 98 (Dec. 1990), $1325-48$ 
Linneman, Peter and Wachter, Susan, "The Impacts of Borrowing Constraints on Homeownership," American Real Estate and Urban Economics Association Journal 17 (Winter 1989), 389-402.

Madrian, Brigitte, "Employment Based Health Insurance and Job Mobility: Is There Evidence of Job-Lock?" Quarterly Journal of Economics 109 (Feb. 1994), 27-54.

Shiller, Robert J. and Allan N. Weiss, "Home Equity Insurance," NBER Working Paper 4830 (Aug. 1994).

Stein, Jeremy C, "Prices and Trading Volume in the Housing market: A Model with Down payment Effects," Quarterly Journal of Economics 110 (May 1995), 379-406.

Topel, Robert H, “Local Labor Markets,” Journal of Political Economy 94 (June 1986), S111-43.

Zorn, Peter M, "Mobility-Tenure Decisions and Financial Credit: Do Qualification Requirements Constrain Home ownership?" American Real Estate and Urban Economics Association Journal 17 (Spring 1989), 1-16. 
Table 1: Summary Statistics by Mover Status

\begin{tabular}{lrrr}
\hline & Whole sample & Non-movers & Movers \\
\hline & & & \\
\% Moved & $14.1 \%$ & & \\
Median loan amount \$ & 140,000 & 136,000 & 170,000 \\
Median appraised property value \$ & 203,007 & 197,012 & 250,000 \\
Mean LTV & $68.8 \%$ & $68.9 \%$ & $68.3 \%$ \\
\% With LTV > 80\% & $13.3 \%$ & $13.4 \%$ & $12.9 \%$ \\
\% Paid mortgage points & $22.0 \%$ & $22.4 \%$ & $19.5 \%$ \\
Median liquid assets \$ & 11,200 & 10,600 & 13,700 \\
Median monthly income \$ & 7,670 & 7,532 & 8,466 \\
Mean age (years) & 39.2 & 39.3 & 39.0 \\
Average years of schooling & 16.7 & 16.7 & 16.8 \\
\% Married & $56.2 \%$ & $55.4 \%$ & $60.5 \%$ \\
\% With children & $29.4 \%$ & $29.0 \%$ & $32.2 \%$ \\
\% Female head of household & $22.9 \%$ & $24.3 \%$ & $14.0 \%$ \\
\% Prior owner & $53.5 \%$ & $54.1 \%$ & $49.7 \%$ \\
& & & \\
\hline Number & 5,778 & 4,965 & 813 \\
\hline
\end{tabular}

Notes: Demographic and employment variables refer to the borrower.

Income and assets are for the borrower and coborrower (if any) combined.

All variables except " $\%$ Moved" are measured at the time of mortgage origination. 
Table 2: Summary Statistics by Initial LTV

\begin{tabular}{lrrr}
\hline & Whole sample & \multicolumn{1}{c}{$\begin{array}{c}\text { LTV } \leq \\
80 \%\end{array}$} & \multicolumn{1}{c}{$\begin{array}{c}\text { LTV }> \\
80 \%\end{array}$} \\
\hline \% Moved & & $14.2 \%$ & $13.5 \%$ \\
Median loan amount \$ & $14.1 \%$ & 144,000 & 139,825 \\
Median appraised property value \$ & 140,000 & 210,002 & 165,000 \\
Mean LTV & 203,007 & $65.9 \%$ & $88.1 \%$ \\
\% With LTV > 80\% & $68.8 \%$ & & \\
\% Paid mortgage points & $13.3 \%$ & $21.7 \%$ & $23.9 \%$ \\
Median liquid assets \$ & $22.0 \%$ & 11,300 & 10,900 \\
Median monthly income $\$$ & 11,200 & 7,895 & 6,667 \\
Mean age (years) & 7,670 & 39.8 & 35.4 \\
Average years of schooling & 39.2 & 16.8 & 16.6 \\
\% Married & 16.7 & $56.4 \%$ & $54.3 \%$ \\
\% With children & $56.2 \%$ & $29.7 \%$ & $27.3 \%$ \\
\% Female head of household & $29.4 \%$ & $23.2 \%$ & $20.6 \%$ \\
\% Prior owner & $22.9 \%$ & $55.7 \%$ & $38.5 \%$ \\
\hline Number & $53.5 \%$ & & \\
\hline Nos: Dor & & 5,012 & 766 \\
\hline
\end{tabular}

Notes: Demographic and employment variables refer to the borrower.

Income and assets are for the borrower and coborrower (if any) combined.

All variables except " $\%$ Moved" are measured at the time of mortgage origination 
Table 3: Summary Statistics for the Sample Counties by Cumulative House Price Change Over the Sample Period

\begin{tabular}{lrr}
\hline & $\begin{array}{c}\text { Counties with less } \\
\text { than } \\
\text { 6\% house price } \\
\text { decline }\end{array}$ & $\begin{array}{c}\text { Counties with more } \\
\text { than }\end{array}$ \\
& & $\begin{array}{c}6 \% \text { house price } \\
\text { decline }\end{array}$ \\
Among home owners with mortgages: & $42 \%$ & $39 \%$ \\
\% Moved in last 5 years & $150,000-175,000$ & $150,000-175,000$ \\
Median house value $\$$ & 58,200 & 55,300 \\
Median annual household income $\$$ & 40.5 & 42.2 \\
Mean age & $39 \%$ & $37 \%$ \\
\% Married & $14 \%$ & $14 \%$ \\
Average education level & some college & some college \\
\hline
\end{tabular}

Source: U.S. Bureau of the Census 1990 and Case Shiller Weiss, Inc 
Table 4: Proportional Hazard Estimates

\begin{tabular}{|c|c|c|c|c|}
\hline & \multicolumn{3}{|c|}{$\mathrm{N}=5,778$} & \\
\hline & 1 & 2 & 3 & 4 \\
\hline Intercept & $\begin{array}{l}-7.098 \\
(0.150)\end{array}$ & $\begin{array}{l}-5.853 \\
(0.203)\end{array}$ & $\begin{array}{l}-5.870 \\
(0.204)\end{array}$ & $\begin{array}{l}-4.334 \\
(0.580)\end{array}$ \\
\hline $\mathrm{w}_{1} * \mathrm{t}$ & $\begin{array}{c}0.141 \\
(0.010)\end{array}$ & $\begin{array}{c}0.146 \\
(0.010)\end{array}$ & $\begin{array}{c}0.146 \\
(0.010)\end{array}$ & $\begin{array}{r}0.147 \\
(0.011)\end{array}$ \\
\hline $\mathrm{w}_{2}$ & $\begin{array}{l}-0.021 \\
(0.188)\end{array}$ & $\begin{array}{l}-0.027 \\
(0.189)\end{array}$ & $\begin{array}{l}-0.026 \\
(0.189)\end{array}$ & $\begin{array}{r}0.039 \\
(0.190)\end{array}$ \\
\hline $\mathrm{w}_{2} * \mathrm{t}$ & $\begin{array}{c}0.033 \\
(0.007)\end{array}$ & $\begin{array}{c}0.037 \\
(0.007)\end{array}$ & $\begin{array}{c}0.038 \\
(0.007)\end{array}$ & $\begin{array}{r}0.036 \\
(0.007)\end{array}$ \\
\hline Contemporaneous LTV: $\gamma 1$ & & $\begin{array}{l}-1.934^{* *} \\
(0.247)\end{array}$ & $\begin{array}{l}-1.934^{* *} \\
(0.247)\end{array}$ & $\begin{array}{r}-1.601^{* *} \\
(0.265)\end{array}$ \\
\hline $\begin{array}{l}\text { Cumulative growth in } \\
\text { house prices: } \gamma^{2}\end{array}$ & & $\begin{array}{c}0.765 \\
(0.968)\end{array}$ & $\begin{array}{c}0.755 \\
(0.971)\end{array}$ & $\begin{array}{c}0.400 \\
(1.027)\end{array}$ \\
\hline $\begin{array}{l}\text { High Original } \\
\text { LTV indicator: } \gamma^{3}\end{array}$ & & $\begin{array}{c}0.052 \\
(0.134)\end{array}$ & $\begin{array}{c}0.057 \\
(0.134)\end{array}$ & $\begin{array}{c}0.102 \\
(0.136)\end{array}$ \\
\hline Liquid assets / house value & & & $\begin{array}{c}0.022 \\
(0.029)\end{array}$ & $\begin{array}{l}-0.008 \\
(0.028)\end{array}$ \\
\hline Married & & & & $\begin{array}{l}0.282^{* *} \\
(0.092)\end{array}$ \\
\hline Children & & & & $\begin{array}{r}0.118 \\
(0.091)\end{array}$ \\
\hline Female head of household & & & & $\begin{array}{l}-0.393^{* *} \\
(0.118)\end{array}$ \\
\hline Younger than age 35 & & & & $\begin{array}{l}0.165^{*} \\
(0.088)\end{array}$ \\
\hline Older than age 55 & & & & $\begin{array}{r}0.163 \\
(0.133)\end{array}$ \\
\hline Years of education & & & & $\begin{array}{l}0.034^{* *} \\
(0.013)\end{array}$ \\
\hline Prior owner & & & & $\begin{array}{r}0.079 \\
(0.086)\end{array}$ \\
\hline Monthly income $\$ 1000$ & & & & $\begin{array}{r}0.003^{+} \\
(0.002)\end{array}$ \\
\hline Paid mortgage points & & & & $\begin{array}{l}-0.452^{* *} \\
(0.096)\end{array}$ \\
\hline $\begin{array}{l}\text { Contemporaneous } \\
\text { market interest rate }\end{array}$ & & & & $\begin{array}{l}-0.303^{* *} \\
(0.052)\end{array}$ \\
\hline og Likelihood & $-4,139$ & $-4,098$ & $-4,097$ & $-4,016$ \\
\hline
\end{tabular}

Notes : Standard errors are in parentheses.

${ }^{+}$Significance at $10 \% \quad *$ Significance at $5 \% \quad * *$ Significance at $1 \%$ 


\section{Frequency}

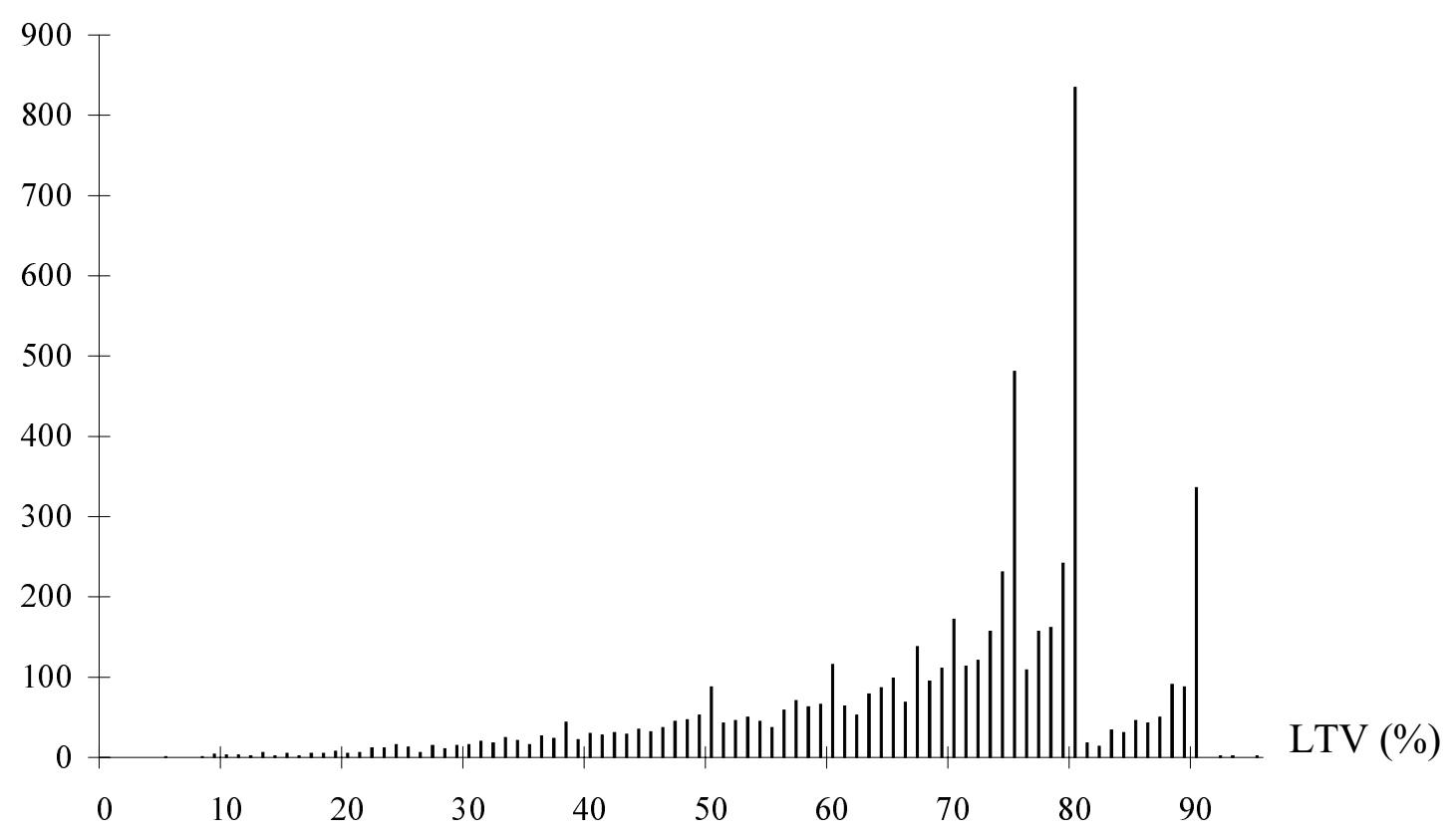

Figure 1: Distribution of Initial Loan-to-Value in the Sample 


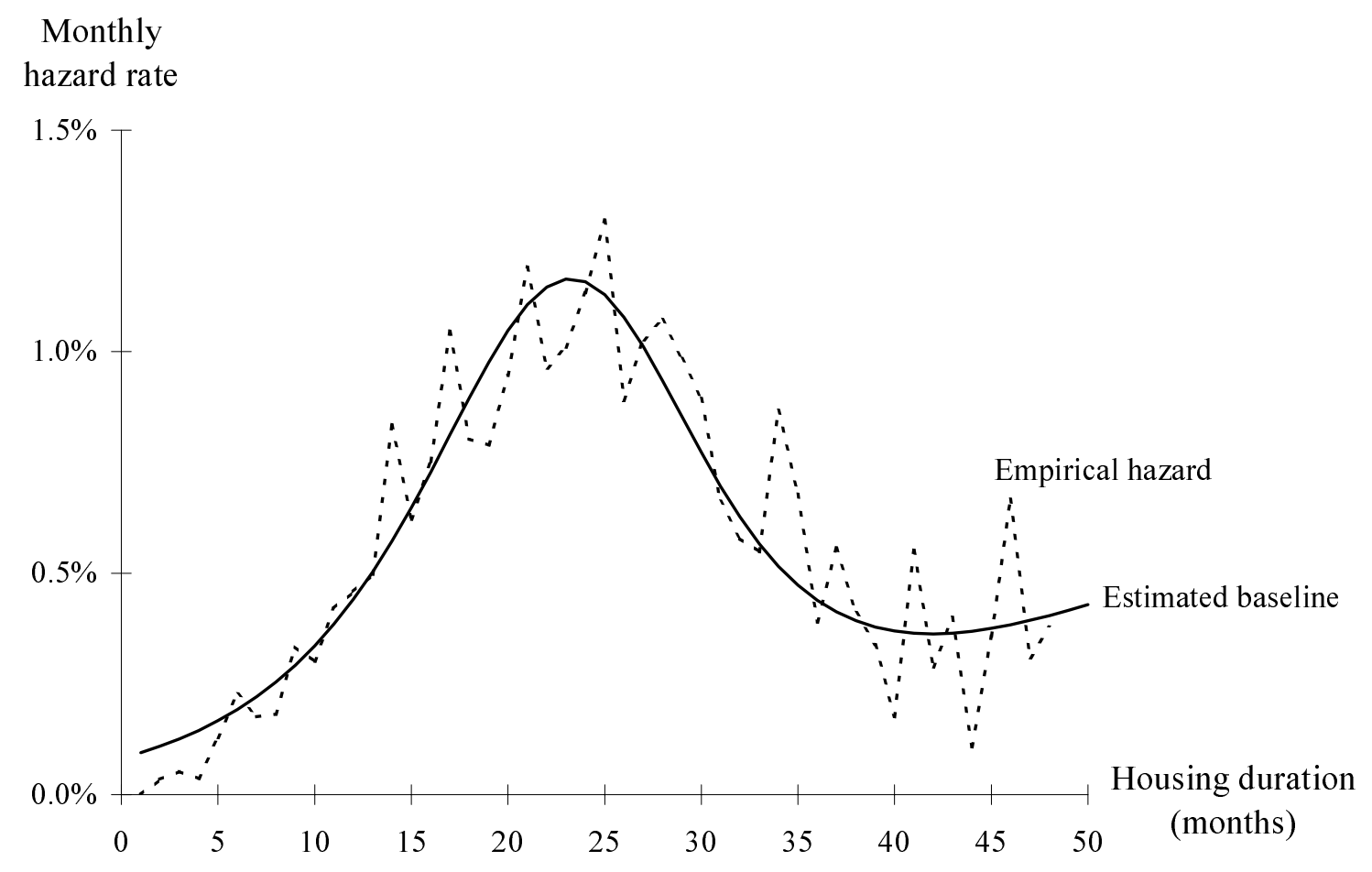

Figure 2: The Empirical and Estimated Baseline Hazards 
Increase in

Mobility rate

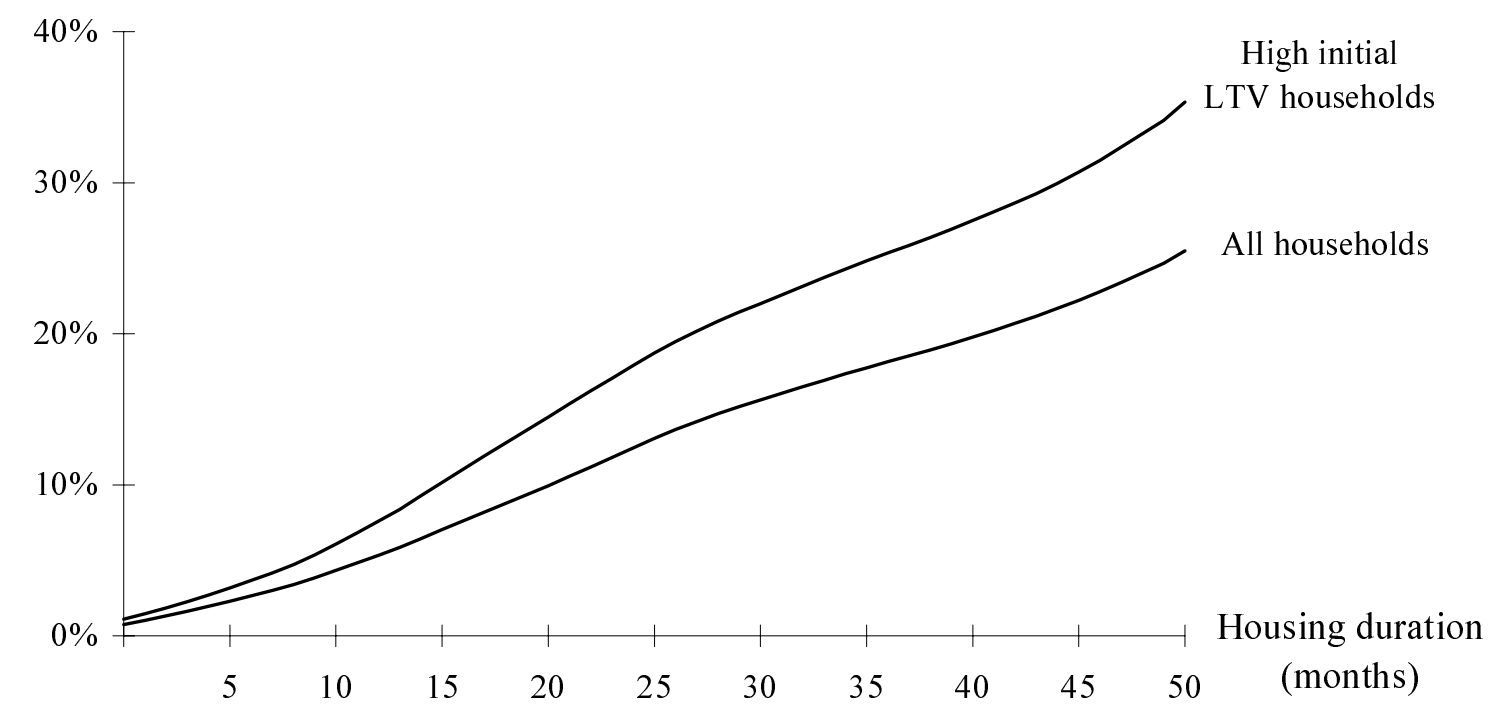

Figure 3: Estimated Increase in Mobility Rates

if Real House Prices had Kept Growing at the 1982-89 Average Rate 
Increase in

Mobility rate

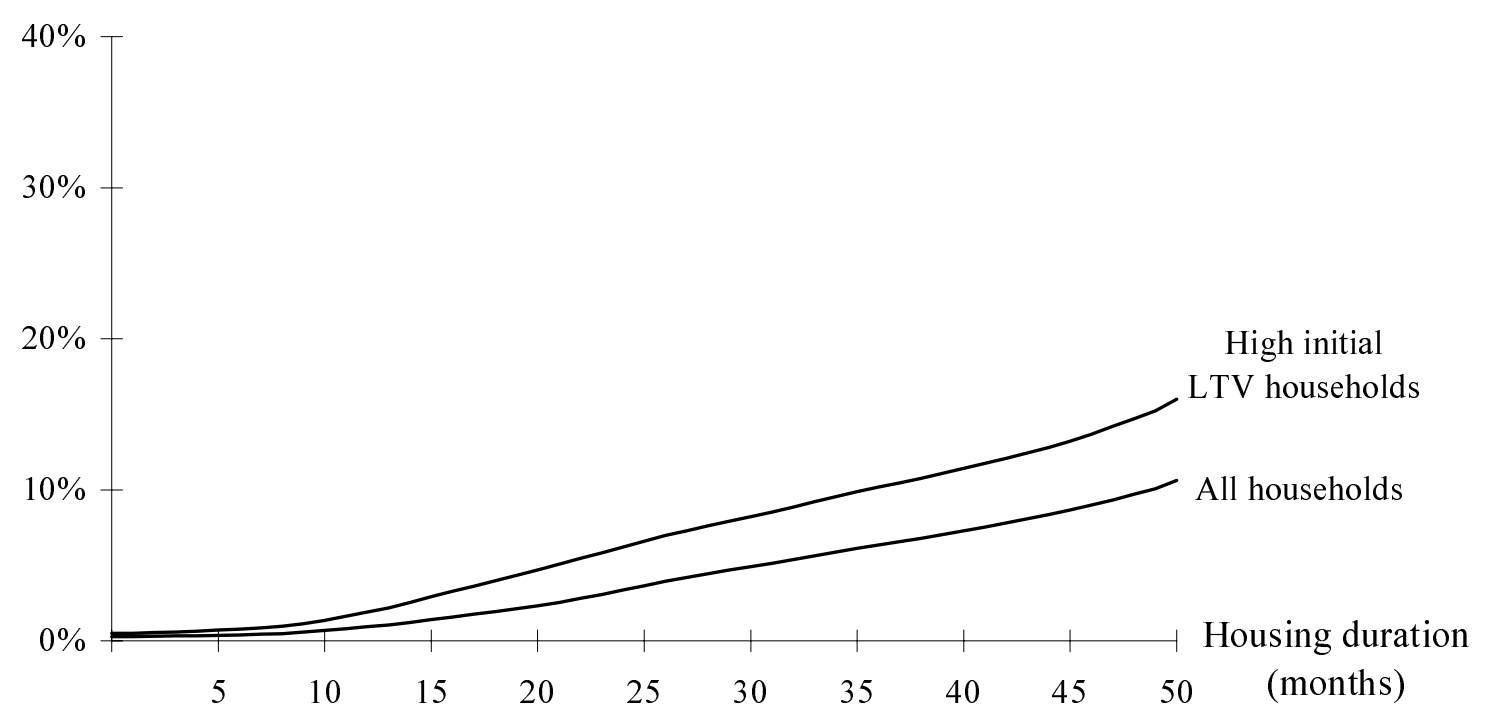

Figure 4: Estimated Increase in Mobility Rates if Real House Prices had Zero Growth 